\title{
Ewingov sarkom i fizioterapija kao dio medicinskog tretmana $u$ rehabilitaciji onkoloških bolesnika
}

1 Hrvoje Gudlin

1 Specijalna bolnica za zaštitu djece s neurorazvojnim i motoričkim smetnjama

\section{Sažetak}

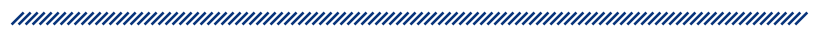

Ewingov sarkom treći je po učestalosti primarni zloćudni tumor kostiju, iza osteosarkoma i hondrosarkoma, te je drugi najčešći zloćudni tumor kostiju kod djece i adolescenata, a čini otprilike 10 do $15 \%$ svih primarnih tumora kostiju. Najčešće je lokaliziran na donjim ekstremitetima (45\%). Slijede zdjelica (20\%), gornji ekstremiteti (13\%), aksijalni skelet i rebra (13\%) te kosti lica, gdje se najrjeđe javlja, u svega $2 \%$ slučajeva. Tumor se razvija u medularnoj šupljini te se širi kroz kost i pokosnicu u meka tkiva. Može biti lokaliziran ili metastazirajući. Tipični su simptomi bol, oteklina, venski crtež, neuroispadi, ograničena pokretljivost, slabost, umor i vrućica. Dijagnostika uključuje rendgensko snimanje, CT, MR, scintigrafiju te biopsiju za postavljanje konačne dijagnoze. Liječenje se sastoji primarno od ciklusa polikemoterapija u trajanju od 12 do 24 tjedana. Nakon toga slijede operacija, radioterapija, kemoradioterapija ili amputacija. Prognoze su za petogodišnje preživljavanje pacijenata s lokaliziranim tumorom oko $70 \%$, a pacijenata s metastazirajućim tumorom oko 20 do $30 \%$. Prognoze su loše kod pacijenata s recidivom tumora, a njih ima oko 30 do $40 \%$. Trećina pacijenata s recidivom tumora ima manje od $20 \%$ šanse da preživi.
U današnje doba javlja se sve veća potreba za fizioterapijom i rehabilitacijom onkoloških bolesnika, kako bi pacijenti ostvarili što veću kvalitetu života. Fizioterapija u tretmanu onkoloških pacijenata započinje već u jedinici intenzivnog liječenja. Kod Ewingova sarkoma fizioterapija ima značajnu ulogu u prijeoperacijskom razdoblju, kao i nakon operacije ili amputacije.

Ključne riječi: Ewingov sarkom, rehabilitacija, fizioterapija, kvaliteta života

Datum primitka: 28.05.2015.

Datum prihvaćanja: 08.09.2015.

\section{Adresa za dopisivanje:}

Hrvoje Gudlin, bacc. physioth.

Specijalna bolnica za zaštitu djece s neurorazvojnim i motoričkim smetnjama

Ivane Brlić-Mažuranić $82 \mathrm{~A}$, Zagreb

Tel.: 0951995910

E-pošta: hrvoje.gudlin@gmail.com

\section{Uvod}

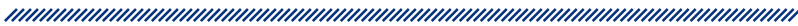

Koštani tumori čine tek $5 \%$ ukupnog broja tumora dječje dobi. Najčešći je osteosarkom, a slijedi Ewingov sarkom $^{1}$. Ewingov sarkom treći je po učestalosti primarni zloćudni tumor kostiju, iza osteosarkoma i hondrosarkoma, te je drugi najčešći zloćudni tumor kostiju kod 
djece i adolescenata, a čini otprilike 10 do $15 \%$ svih primarnih tumora kostiju. Godišnja je incidencija 0,6 na 1000000 ljudi, a obično se javlja između desete i dvadesete godine života. Nešto se češće javlja kod djece muškog spola $(1,5: 1 \text { u odnosu na žensku djecu })^{2,3}$. Bolest nije povezana s okolinskim faktorima, kao ni s naslijeđem, s obzirom na to da se genske promjene događaju nakon rođenja. Isto tako, bolest se ne može prevenirati ${ }^{4}$. Ewingov sarkom najčešće je lokaliziran na donjim ekstremitetima (45\%). Slijede zdjelica (20\%), gornji ekstremiteti $(13 \%)$, aksijalni skelet i rebra (13\%) te kosti lica, gdje se najrjeđe javlja, u svega $2 \%$ slučajeva ${ }^{3}$. Od kostiju najčešće bude zahvaćen femur ${ }^{3,5}$. Obično se pojavi na metafizi duge kosti ili neposredno u blizini metafize, iako može zahvatiti i plosnate kosti (zdjelica, lopatica) ${ }^{6}$. Do bolesti dolazi zbog karakteristične kromosomske translokacije $\mathrm{t}(11 ; 22)$ (q24;q12), koja uzrokuje fuziju gena EWS s genom za transkripcijski čimbenik FLI-1. Taj fuzionirani gen EWS-FLI-1 funkcionira kao onkogen koji stimulira rast tumorskih stanica. Tumor se razvija u medularnoj šupljini te se širi kroz kost i pokosnicu u meka tkiva. Može biti lokaliziran ili metastazirajući. Metastazira hematogeno u pluća, organe, druge kosti te rijetko u limfne čvorove ${ }^{2}$.

\section{Simptomi, klinička slika i dijagnostika}

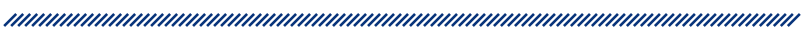

Tipični su simptomi bol, oteklina koja je bolna na pritisak, venski crtež koji, kao i oteklina, ukazuje na ekstraosalni prodor tumora, neuroispadi koji se javljaju u slučaju kompresije živca oko tumora, ograničena pokretljivost ako je tumor u području oko zgloba te slabost, umor i vrućica. Bol se često javlja noću pa remeti san. Bolovi mogu popuštati pa opet jačati, a te se epizode izmjenjuju sa sve kraćim periodima stanki te na kraju nastupi trajno stanje s jakim bolovima ${ }^{1,5,6,7}$. Nad tumorom je koža topla, pacijent često ima povišenu temperaturu, povećana je sedimentacija eritrocita i više je leukocita u krvi .

Točna je dijagnoza ključna za odgovarajuću kliničku skrb oko pacijenta. Određene kliničke informacije su iznimno važne za diferencijaciju Ewingova sarkoma od nekih drugih tumora dječje dobi³. Kreće se s rendgenskim snimanjem suspektnog područja. Tipično se može vidjeti periostalna reakcija u obliku razvoja slojeva nove kosti, što izgledom podsjeća na lukovicu ${ }^{2,5}$. Nakon toga potrebno je učiniti CT i MR zahvaćene kosti tj. područja, CT toraksa kako bi se rano otkrile eventualne metastaze i scintigrafiju kosti te razmotriti potrebu za biopsijom koštane srži. Za definitivno postavljanje dijagnoze Ewingova sarkoma nužno je napraviti biopsiju ${ }^{1,5,8}$.

\section{Mogućnosti liječenja i prognoze}

Tretman onkološkog bolesnika zahtijeva multidisciplinarni pristup koji uključuje suradnju ortopeda, onkologa, plastičnog kirurga, patologa, radiologa, kao i niz ostalih djelatnika medicinske struke ${ }^{7}$. Ključni oblici liječenja u ranom stadiju bolesti uključuju kiruršku intervenciju, kemoterapiju i radioterapiju te rehabilitacijske postupke ${ }^{9}$. Liječenje se sastoji primarno od ciklusa polikemoterapija u trajanju od 12 do 24 tjedana, a svrha im je smanjiti aktivnost malignih stanica i uništiti mikrometastaze te samim time povećati mogućnost izvođenja radikalnoga kirurškog zahvata s negativnim resekcijskim rubom, što znači da je rub resekcije čist od tumorskih stanica. Bolesnici koji odgovore na primarnu terapiju nastavljaju s lokalnim liječenjem, a to uključuje: kirurški zahvat s prijeoperacijskom radioterapijom ili bez nje, definitivnu kemoradioterapiju ili amputaciju, koja se radi ako je tumor vrlo opsežan ili u slučaju infekcije. Primarne opcije kirurške rekonstrukcije uključuju uzimanje autogenoga koštanog transplantata (dio kosti uzet s nekog drugog dijela tijela, a može se i vaskularizirati), koštanog alotransplantata (dio kosti uzet od druge osobe) ili izradu metalne endoproteze ${ }^{10}$. Adjuvantna kemoterapija slijedi nakon kirurškog zahvata neovisno o resekcijskim rubovima. Bolesnici koji ne reagiraju na primarnu terapiju nastavljaju liječenje radioterapijom s kirurškim zahvatom ili bez njega, uz kemoterapiju ${ }^{1,5}$.

Treba znati da tretman pacijenta, kemoterapija i radioterapija, štete i zdravim stanicama, što kasnije može negativno utjecati na mozak te prouzročiti teškoće učenja. Također, mogu se javiti problemi sa sluhom, vidom, teškoće u rastu i razvoju, kao i oštećenje srca i krvožilnog, dišnog i ostalih tjelesnih sustava. Naposljetku, mogu se razviti i drugi karcinomi ${ }^{4}$.

Prognoze su za petogodišnje preživljavanje pacijenata s lokaliziranim tumorom oko $70 \%$, a pacijenata s metastazirajućim tumorom oko 20 do $30 \% \%^{4}$. Upravo zahvaljujući multidisciplinarnom pristupu, tj. kombinaciji ke- 
moterapije s kirurškim postupcima i/ili radioterapijom, stopa petogodišnjeg preživljavanja napredovala je do $60 \%$ i više ${ }^{8}$. Govoreći o prognozama, u obzir se uzimaju veličina tumora, lokacija primarnog tumora, odgovor na kemoterapiju, dob djeteta, a nekad i kirurški zahvat kao dio inicijalnog tretmana ${ }^{4,11}$. Povoljni su prognostički čimbenici distalni smještaj primarnog tumora, normalna vrijednost LDH-a (laktat dehidrogenaza), nepostojanje diseminacije bolesti pri dijagnozi te lokalizirani tumor. Prognoze su loše kod pacijenata s recidivom tumora, a njih ima oko 30 do $40 \%$. Otprilike trećina pacijenata s recidivom tumora imaju manje od $20 \%$ šanse da prežive. Osobito nepovoljne prognoze odnose se na pacijente kojima se bolest ponovno pojavi unutar 24 mjeseca. Davanje jakih i agresivnih terapija kod takvih pacijenata, uključujući visoke doze, može odgoditi, ali ne i prevenirati smrtni ishod ${ }^{12}$.

\section{Fizioterapija u onkologiji}

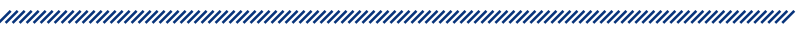

Onkologija (grč. onkos - tumor, logos - znanost) je dio medicine koji se bavi proučavanjem i liječenjem tumora, malignih neoplazmi i temelji se na prevenciji, ranom otkrivanju i pravodobnom liječenju tumora. U suvremeno su doba tumori sve učestaliji, a po smrtnosti su među vodećima ${ }^{13}$.

Liječenje i rehabilitacija onkoloških pacijenata zahtijeva suradnju velikog broja zdravstvenih i socijalnih djelatnika, kao i volontera, obitelji i društva općenito. Proces liječenja i rehabilitacije ne počinje nakon operacije ili u poodmaklom stadiju bolesti. Počinje onog trenutka kad se postavi konačna dijagnoza bolesti. U tom trenutku pacijent, njegova obitelj, zdravstveni tim koji skrbi o njemu te svi oni koji su na bilo koji način povezani s pacijentom i njegovim stanjem kreću u borbu protiv bolesti.

U današnje se doba javlja sve veća potreba za fizioterapijom i rehabilitacijom onkoloških bolesnika, kako bi pacijenti ostvarili što veću kvalitetu života. Rehabilitacija je potrebna u svim fazama liječenja, a najpotrebnija je nakon kirurškog zahvata ${ }^{13}$.

Fizioterapija je dio procesa medicinske rehabilitacije. Omogućuje održavanje, razvijanje i obnovu funkcionalnih sposobnosti liječenih te uspješan povratak u aktivnosti svakodnevnog i profesionalnog života. Fizioterapija kod onkoloških pacijenata uključuje procjenu i prijeoperacijsku pripremu, intervenciju te evaluaciju provedenog, a u tretmanu onkoloških pacijenata započinje već u jedinici intenzivnog liječenja pri provođenju postupaka za uspostavu homeostaze ${ }^{14}$. $U$ jedinici intenzivnog liječenja fizioterapija ima tri osnovna zadatka ${ }^{13}$ :

- vježbama disanja nastoji se brže eliminirati anestetik iz tijela

- pozicioniranjem se nastoji spriječiti nastanak dekubitusa

- pripremiti pacijenta za vertikalizaciju.

Fizioterapija bi trebala pratiti promjene u tehnologiji i znanosti te uz usvajanje vještina i reproduciranje stečenih znanja pridonositi kreativnosti u primjeni ${ }^{15}$. U onkološkom je liječenju fizioterapija vrlo specifična jer se koncentrira na aktivnosti svakodnevnog života, ukupnu kvalitetu života te edukaciju pacijenta i obitelji, a uz to nastoji pružiti podršku bržem oporavku gotovo svih sustava $^{13}{ }^{14}$. Prijeoperacijskom pripremom nastoji se spriječiti i ublažiti odstupanje od fiziološkog te skratiti vrijeme oporavka. Fizioterapeut provodi tehnike respiratorne terapije, nastoji očuvati mobilnost zglobova i mišićnu snagu kroz aktivne, pasivne i asistirane pokrete te educira pacijenta i njegovu obitelj u svrhu poboljšanja kvalitete života ${ }^{1,9,14}$. Ciljevi su poslijeoperacijske fizioterapije i rehabilitacije poboljšanje stanja preostalog zdravlja otkrivanjem čimbenika rizika koji mogu pogoršavati opće stanje i kvalitetu života onkoloških bolesnika, prevencija nastanka komplikacija i onesposobljenja putem radnoterapijskih programa i edukacije, programi podrške u vidu logopedskog tretmana, psihološke podrške te protetičke i ortotičke opskrbe ${ }^{14}$.

U cjelovitom fizioterapijskom procesu onkoloških pacijenata fizioterapeut mora nastojati pružiti maksimum svih onih vještina kojima će na neki način pomoći pacijentu, pripremiti ga na nadolazeće situacije, olakšati mu borbu s bolešću, pomoći mu pri aktivnostima svakodnevice i samozbrinjavanja te mu pružiti fizičku i psihičku potporu. 


\section{Fizioterapija kod osoba s Ewingovim sarkomom}

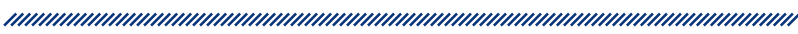

Fizioterapija kod Ewingova sarkoma sa sobom nosi brojne izazove i ne suviše jednostavne situacije. Razlog tomu prvenstveno stoji u činjenici da najviše obolijevaju djeca i mladi, a u rijetkim slučajevima i vrlo mala djeca. Raditi s djecom i mladima lijep je dio fizioterapije, ali isto tako i najteži dio. U teškim situacijama, stanjima povlačenja u sebe, ljutnje, poricanja, depresije i neprihvaćanja novonastale situacije, svaki zdravstveni djelatnik, osim što se drži okvira svoje profesije, trebao bi mladim osobama i djeci biti osoba od povjerenja i podrška u svim aspektima bolesti. Uz djecu, tu su i njihovi roditelji te cjelokupna obitelj. Tretman ovakvih pacijenata stoga nije nimalo jednostavan ni klasičan fizioterapijski tretman.

Jednostavno rečeno, fizioterapijski tretman može se podijeliti na prijeoperacijski i poslijeoperacijski dio. U fazi prijeoperacijske fizioterapije terapeut procjenjuje opće stanje pacijenta, kao i stanje zahvaćenog dijela tijela, na temelju čega planira intervenciju te educira pacijenta i obitelj, kako bi svi bili uključeni u tretman. Važno je pripremiti i jačati zahvaćeni ud, tj. dio tijela na kojemu će se izvršiti kirurški zahvat, pritom izbjegavajući velike težine na zahvaćenom ekstremitetu, održavati aerobni kapacitet, prevenirati eventualne komplikacije i u što boljem stanju dočekati kirurški zahvat ${ }^{14,16}$. Treba imati na umu i strah pacijenta i njegove obitelji te ih $\mathrm{i}$ na tom polju što više pripremiti za nadolazeći zahvat. Poslijeoperacijska fizioterapija nastoji aerobnim vježbama, vježbama jačanja muskulature, aktivnim i pasivnim vježbama za održavanje i postupno povećanje opsega pokreta te, ako postoje uvjeti, vježbama u vodi, kao potpuno drukčijem terapijskom mediju, pomoći pacijentu u oporavku. Nakon zahvata potreban je oprez pri provođenju terapijskih postupaka zbog smanjenog i usporenog tijeka zacjeljivanja nakon kemoterapije ${ }^{9,16}$.

Kod pacijenata kojima je amputiran ud fizioterapija ponovno nudi nove izazove i zadatke. Sama amputacija rezultirat će kraćim boravkom u bolnici te bržim početkom rehabilitacije. Pacijent će biti u mogućnosti uključiti se u razne oblike aktivnosti, doduše, uz ograničenja, ali bit će sposoban izvoditi sve one aktivnosti koje osjeća da može ${ }^{17}$. Svaka osoba gubitak uda doživljava na svoj način, ali svima je zajedničko da se dogodi velika promjena u kratkom vremenskom periodu, kojoj se mo- raju prilagoditi i s kojom moraju živjeti ostatak života. Mladima koji još nisu završili rast bit će otežan razvoj i uspostavljanje normalne posture, biomehanike i ravnoteže. Veliku ulogu u pogledu na amputaciju ima i estetika, pogotovo kod mladih osoba. Može se javiti strah od neprihvaćanja u socijalnu sredinu, kao i manjak samopouzdanja te strah same osobe od uključivanja u društveni život. Zdravstveni tim, obitelj i društvo ovdje moraju pružiti maksimalnu potporu i poticati pacijenta na privikavanje i prihvaćanje situacije. Fizioterapeut ima ulogu educirati pacijenta o novonastaloj situaciji i njezinu utjecaju na svakodnevicu. Također, fizioterapeut i ostali članovi medicinskog tima u obzir moraju uzeti pacijentov osjet, bol, stabilnost, deformitet, snagu, funkcionalnu aktivnost i emocije ${ }^{17}$. Većina pacijenata nakon amputacije mora se naviknuti na nošenje proteze te je tu potrebno uzeti u obzir dug period prilagodbe. Fizioterapeut uči pacijenta pravilno se koristiti protezom i ostalim pomagalima za kretanje, npr. štakama ${ }^{16}$. Važno je da pacijent nauči pravilno aplicirati protezu, pravilno je skinuti, upotrebljavati je u aktivnostima svakodnevnog života kao što su hod, vožnja javnim prijevozom, poslovi u domaćinstvu i sl., kod djece, naravno, igranje s vršnjacima, a tu je fizioterapeut od velike pomoći.

\section{Zaključak}

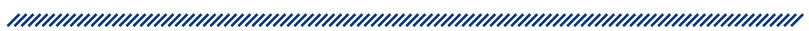

Susret s dijagnozom kao što je Ewingov sarkom ili bilo koji drugi zloćudni tumor uvijek predstavlja veliki šok, stres, tugu i nevjericu. Sama činjenica da je riječ o djetetu ili mladoj osobi daje još veću težinu. Potreba za fizioterapijom kao jednom od metoda medicinskog tretmana onkoloških pacijenata izražena je u sve većoj mjeri. Tretman bez fizioterapije nije cjelovit medicinski tretman jer osoba nema priliku ostvariti punu kvalitetu života, a upravo je to jedan od ciljeva tretmana. Društvo mora izići iz okvira stereotipnih izraza da su onkološki pacijenti oni koji „umiru od raka“ i boriti se skupa s njima za što bolji život i povoljnije posljedice liječenja. Fizioterapija bi kroz pozitivne rezultate tretmana trebala promovirati svoju učinkovitost i svrsishodnost. Medicinski tim mora djelovati kao cjelina u koju svaki član ugrađuje dio znanja, iskustva i vještina, a sve u svrhu što kvalitetnijeg tretmana pacijenta. 


\section{Literatura}

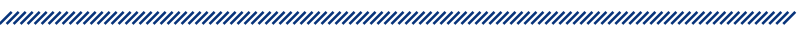

1. Vrcić-Kiseljak Lj, Antolić D, Rašić H. Fizioterapija u liječenju oboljelih od tumora. Skripta za internu upotrebu studenata Zdravstvenog veleučilišta. Zagreb; 2007.

2. Damjanov I, Jukić S, Nola M. Patologija. Zagreb: Medicinska naklada; 2011.

3. Burchill SA. Ewing's sarcoma: diagnostic, prognostic, and therapeutic implications of molecular abnormalities. Journal of Clinical Pathology. 2003;56:96-102.

4. Ewing's sarcoma [Internet]. Dostupno na: www.webmd. com/cancer/ewings-sarcoma? (pristupljeno 24.05.2015.)

5. Vrdoljak E, Šamija M, Kusić Z, Petković M, Gugić D, Krajina Z. Klinička onkologija. Zagreb: Medicinska naklada; 2013.

6. Medicinska enciklopedija, svezak 2. Zagreb: Jugoslavenski leksikografski zavod; 1967.

7. Mavrogenis AF, Ruggieri P. Therapeutic approaches for bone sarcomas. U: Heymann D. Bone Cancer: Primary Bone Cancers and Bone Metastases. Academic Press; 2015.

8. Paulussen $M$, Bielack $S$, Jürgens $H$, Casali PG, ESMO Guidelines Working Group.. Ewing's sarcoma of the bone: ESMO clinical recommendations for diagnosis, treatment and follow-up. Annals of Oncology. 2009;20 Suppl 4:140-142.

9. Dincer F, Dincer M, Baskaya MK. Results of the combined treatment of paediatric intraspinal tumours. Paraplegia 1992;30(10);718-728.

10. Bernstein M, Kovar H, Paulussen M, Randall LR, Schuck A, Teot LA, Juergens H. Ewing's sarcoma family of tumors: Current management. Oncologist. 2006;11(5):503-519.

11. Pritchard D, Dahlin D, Dauphine R, Taylor W, Beabout J. Ewing's sarcoma - a clinicopathological and statistical analysis of patients surviving five years or longer. Journal of bone and joint surgery. 1975;57(1):10-6.

12. Cotterill SJ, Ahrens S, Paulussen M, Jürgens HF, Voûte PA, Gadner H, Craft AW. Prognostic factors in Ewing's tumor of bone: Analysis of 975 patients from the European Intergroup Cooperative Ewing's Sarcoma Study Group. Journal of Clinical Oncology. 2000;18(17):3108-3114.

13. Milas I, Vrcić - Kiseljak Lj. Liječenje i rehabilitacija u onkologiji. U: Vrcić - Kiseljak Lj. i sur. Fizioterapija u onkološkom liječenju i rehabilitaciji - odabrane teme. Zagreb: Medicinska naklada; 2014.

14. Kiseljak D, Vrcić - Kiseljak Lj. Fizioterapija u onkološkoj rehabilitaciji. U: Vrcić-Kiseljak Lj. i sur. Fizioterapija u onkološkom liječenju i rehabilitaciji - odabrane teme. Zagreb: Medicinska naklada; 2014.

15. Vrcić - Kiseljak Lj. i sur. Fizioterapija u onkološkom liječenju i rehabilitaciji - odabrane teme. Zagreb: Medicinska naklada; 2014
16. Ewing's Sarcoma. Physical Therapy Management (current best evidence) [Internet]. Dostupno na: www. physio-pedia.com/Ewing's_Sarcoma\#Physical_Therapy_Management_.28current_best_evidence.29 (pristupljeno 24.05.2015.)

17. Craft AW. Prosthetic replacement surgery for bone tumours - cure at less cost? British Journal of Cancer. 1991;63(2):173-175. 


\section{EWING'S SARCOMA AND PHYSIOTHERAPY AS A PART OF MEDICAL TREATMENT IN THE REHABILITATION OF ONCOLOGICAL PATIENTS}

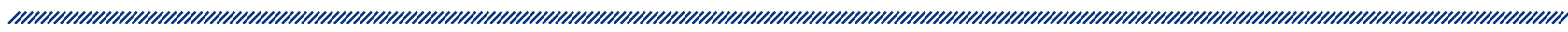

1 Hrvoje Gudlin

1 Special hospital for children with neurodevelopmental disorders

\section{Abstract}

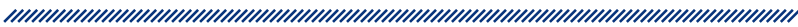

Ewing's sarcoma is the third most common primary malignant bone tumor, following osteosarcoma and chondrosarcoma, it is also the second most common malignant bone tumor in children and adolescents, and makes up about 10 to $15 \%$ of all primary bone tumors. In most cases, it is localized in the lower extremities $(45 \%)$, followed by the pelvic region (20\%), the upper extremities (13\%), the axial skeleton and the ribs (13\%) and the face skeleton (2\%). The tumor arises in the medullary cavity and spreads through the bone and periosteum to soft tissues. It can be localized or metastatic. Typical simptoms are pain, swelling, telangiectasias, neurological deficits, limited mobility, weakness, tiredness and fever. Diagnostics includes X-ray scanning, CT, $M R I$, scintigraphy and, for the final diagnosis, biopsy. The treatment consists primarily of polychemotherapy cycles lasting 12-24 weeks, followed by surgery, radiotherapy, chemoradiotherapy or amputation. The 5-year survival rate of patients with localized tumor is about $70 \%$ and with metastatic tumor it is about $20-30 \%$. The prognosis is poor for patients with tumor relapse which occurs in $30-40 \%$ of the patients. About $30 \%$ of the patients with tumor relapse have less than $20 \%$ chance of survival. Nowadays, there is a growing need for physiotherapy and rehabilitation in the treatment of oncological patients, to help them to achieve the highest possible quality of life. Physiotherapy in the treatment of oncological patients starts in the intensive care unit. Physiotherapy in Ewing's sarcoma treatment plays an important role in the preoperative, postoperative and postamputation period.

Keywords: Ewing's sarcoma, rehabilitation, physiotherapy, quality of life 